OPEN ACCESS

Edited by:

Laurent Dufossé,

Université de la Réunion, France

Reviewed by:

Katarina Veljovic,

University of Belgrade, Serbia Blaženka Kos,

University of Zagreb, Croatia

${ }^{*}$ Correspondence: Je-Ruei Liu jrliu@ntu.edu.tw

Specialty section: This article was submitted to

Food Microbiology,

a section of the journal Frontiers in Microbiology

Received: 25 April 2020 Accepted: 17 June 2020 Published: 15 July 2020

Citation:

Chang-Liao W-P, Lee A, Chiu Y-H,

Chang H-W and Liu J-R (2020) Isolation of a Leuconostoc mesenteroides Strain With Anti-Porcine Epidemic Diarrhea Virus Activities From Kefir Grains. Front. Microbiol. 11:1578. doi: 10.3389/fmicb.2020.01578

\section{Isolation of a Leuconostoc mesenteroides Strain With Anti-Porcine Epidemic Diarrhea Virus Activities From Kefir Grains}

\author{
Wan-Ping Chang-Liao', An Lee', Yu-Han Chiu', Hui-Wen Chang ${ }^{2}$ and Je-Ruei Liu' ${ }^{1,3,4,5 *}$ \\ 1'Institute of Biotechnology, National Taiwan University, Taipei, Taiwan, ${ }^{2}$ School of Veterinary Medicine, National Taiwan \\ University, Taipei, Taiwan, ${ }^{3}$ Department of Animal Science and Technology, National Taiwan University, Taipei, Taiwan, \\ ${ }^{4}$ Center for Biotechnology, National Taiwan University, Taipei, Taiwan, ${ }^{5}$ Agricultural Biotechnology Research Center, \\ Academia Sinica, Taipei, Taiwan
}

Swine grown under commercial conditions are vulnerable to environmental exposure to several viruses, which may cause infectious diseases and spread easily and rapidly, resulting in significant economic losses in animal husbandry. Previous studies have suggested that probiotics seem to be a new and promising alternative to vaccinations to protect animals against potential viral infections. In this study, we used the Vero cell culture model of infection to study porcine epidemic diarrhea virus (PEDV). We screened lactic acid bacteria $(\mathrm{LAB})$ with anti-PEDV potential from kefir grains, which are starter cultures used to ferment milk into kefir. Twenty-nine LAB strains were isolated and identified as Enterococcus durans, Lactobacillus kefiri, Lactococcus lactis, and Leuconostoc mesenteroides, according to $16 \mathrm{~S}$ ribosomal RNA ( $\mathrm{rRNA}$ ) and rpoA gene sequence analyses. The anti-PEDV activities of the LAB intracellular extracts were compared, and the intracellular extracts of $L n$. mesenteroides showed higher anti-PEDV activities than that of the other species. Among the Ln. mesenteroides strains, a strain designated YPK30 showed a higher growth rate than that of the other strains and was further evaluated for its anti-PEDV activity. The results showed that the intracellular extracts of Ln. mesenteroides YPK30 possessed in vitro prophylactic, therapeutic, and direct-inhibitory effects against PEDV in the Vero cell model. The expression levels of Type 1 interferon (IFN)-dependent genes, including Myxovirus resistance 1 ( $M X 1$ ) and interferon-stimulated gene 15 (ISG15), were significantly increased after treatment with intracellular extracts of Ln. mesenteroides YPK30 for $24 \mathrm{~h}$. Such expression suggests that the anti-PEDV activity of $L n$. mesenteroides YPK30 could be attributed to its up-regulatory effect on the expression of MX1 and ISG15 genes. These results suggested that Ln. mesenteroides YPK30 has the potential to provide some levels of host protection against PEDV infections.

Keywords: Leuconostoc mesenteroides, antiviral activity, kefir, porcine epidemic diarrhea virus, interferon-dependent genes 


\section{INTRODUCTION}

In order to increase swine and poultry production, it is common to raise animals in high-density populations. Swine grown under commercial conditions are vulnerable to environmental exposure to several viruses. Some viruses may cause infectious diseases, which are spread easily and rapidly cause significant economic losses in animal husbandry. Vaccination is one of the most efficient strategies to prevent viral diseases and control infections and is the current industry standard. Efficacious vaccines have been developed and applied successfully for the prevention of several infectious viral diseases in swine, such as porcine parvovirus (PPV), foot-and-mouth disease virus (FMDV), porcine circovirus type 2 (PCV2), and transmissible gastroenteritis virus (TGEV; Meng, 2012; Gerdts and Zakhartchouk, 2017). However, some of the vaccination methods require the operator to handle each animal, induce the stress on the animal, and are time-consuming and costly (Marangon and Busani, 2007). Although efficacious vaccines are available to reduce the impact of the infectious viruses mentioned above, unfortunately, substantial challenges remain in obtaining safe and efficacious vaccines for a variety of newly emerging and re-emerging viruses, such as African swine fever virus and porcine epidemic diarrhea virus (PEDV; Lee, 2015). PEDV is a member of the genus Alphacoronavirus in the family Coronaviridae of the order Nidovirales and has emerged as a significant pathogen causing lethal watery diarrhea, vomiting, and dehydration in nursing piglets. Highly pathogenic strains of PEDV have mortality rates of $50-90 \%$ in neonatal piglets, which has resulted in huge economic losses to the swine industry worldwide (Koonpaew et al., 2019; Wang et al., 2019). Accumulated evidence indicates that PEDV encodes defensive mechanisms to evade virus recognition by host pattern recognition receptors (PRRs) present on antigen-presenting cells, inhibit interferon (IFN) induction, and antagonize IFN signaling and antiviral effector machinery (Hao et al., 2019; Koonpaew et al., 2019). PEDV has been studied extensively and some vaccines have been developed against PEDV, but the efficacy of these vaccines in the field remains questionable (Wang et al., 2019).

Probiotics, which are live microorganisms that when administered in adequate amounts confer a health benefit on the host, have long been used as feed additives because of their abilities to normalize gut microbiota, boost the immune system, prevent diarrhea, and improve feed conversion efficiency (Fontana et al., 2012; Alonso and Guarner, 2013). The effect of probiotics is achieved mainly through the intervention on gut microbiota, which increases the levels of beneficial bacteria and decreases the pathogenic populations in the gastrointestinal tract (Liu et al., 2015; Yadav and Shukla, 2019). In addition to the microbiota-modulatory properties, recent studies showed that the immunomodulatory activity of probiotics is another important mechanism of action of probiotics for the inhibition of pathogens (Llewellyn and Foey, 2017; Azad et al., 2018). Those immunoregulatory probiotics provide host protection against pathogenic infections by modulating innate and adaptive antiviral immune responses (Villena et al., 2016). Several probiotic strains, most of them belonging to Lactobacillus and Bifidobacterium genera, have been shown to perform antiviral activities (Villena et al., 2016; Arena et al., 2018). These antiviral activities could be mediated by the immunomodulatory properties of probiotics because it was observed that administration of probiotics induced the expression of IFN and interferonstimulated genes (ISGs), which are crucial components of the IFN responses and play a key role in establishing an antiviral state for virus clearance and restriction of spread (Zelaya et al., 2015; Villena et al., 2016; Arena et al., 2018; Eguchi et al., 2019). If probiotics have antiviral activity, it seems to be a new and promising alternative to vaccinations to protect animals against potential viral infections (Al Kassaa et al., 2014).

Kefir is an acidic and mildly alcoholic fermented milk product that is believed to have many beneficial activities, such as hypocholesterolemic activity, antibacterial and antifungal activities, antitumor activity, immunomodulatory activity, and quickening of wound healing (Bourrie et al., 2016). Traditionally, kefir is produced from milk fermented with a mixed microflora confined to a matrix of discrete kefir grains, which are a combination of bacteria and yeasts in a symbiotic matrix (Marshall and Cole, 1985). Various bacteria and yeasts have been identified in kefir grains. The bacteria present in kefir grains may include Acetobacter, Bifidobacterium, Lactobacillus, Lactococcus, Leuconostoc, Oenococcus, and Streptococcus, while the yeasts present in kefir grains may include Candida, Kluyveromyces, and Pichia (Lin et al., 1999; Wang et al., 2012; Bourrie et al., 2016). Numerous bacterial strains with specific properties, such as hypocholesterolemic effect, antiallergenic effect, immunoregulatory effects, and antipathogenic activities, have been isolated from kefir grains (Prado et al., 2015). However, to the best of our knowledge, following a thorough review of the relevant literature, there has been no study to isolate bacterial strains with antiviral activities from kefir grains.

In the present study, we used the Vero cell culture model of infection by PEDV to screen lactic acid bacteria (LAB) with anti-PEDV activities from kefir grains. The anti-PEDV activities of the LAB strains were evaluated in prophylactic, therapeutic, and direct-inhibitory models. The strains with anti-PEDV activities were further studied to define their effects on the expression of Type 1 IFN-dependent genes, including 2'-5'-oligoadenylate synthetase 1 (OAS1), Myxovirus resistance 1 (MX1), and interferon-stimulated gene 15 (ISG15) in Vero cells.

\section{MATERIALS AND METHODS}

\section{Isolation of LAB Strains From Kefir Grains}

A total of 29 LAB strains were isolated from kefir grains according to the method described by Lin et al. (1999). The LAB isolates were cultured in de Mann, Rogosa, Sharpe (MRS) broth (Oxoid, Basingstoke, UK) at $37^{\circ} \mathrm{C}$ for $16 \mathrm{~h}$ without shaking. The bacterial concentrations were measured by optical density readings at $600 \mathrm{~nm}$ or by traditional colony counting methods (Vinderola et al., 2000).

\section{Identification of the LAB Isolates}

For colony morphological observation, the LAB isolates were cultivated on MRS agar plates (Oxoid) or blood agar plates 
(Merck, Darmstadt, Germany) at $37^{\circ} \mathrm{C}$ for $24 \mathrm{~h}$ and then observed. For cell morphological observation, the LAB isolates were cultured in MRS broth (Oxoid) at $37^{\circ} \mathrm{C}$ for $16 \mathrm{~h}$ without shaking. The bacterial cells were harvested by centrifugation at 5,000 $\mathrm{g}$ for $20 \mathrm{~min}$ at $4^{\circ} \mathrm{C}$, stained with Gram stain (SigmaAldrich, St. Louis, MO, USA) according to the manufacturer's instructions, and observed under a microscope. Unstained bacteria were observed under a phase-contrast microscope.

Molecular identification of the bacterial isolates was performed by the methods described by Weisburg et al. (1990) and Naser et al. (2005). Genomic DNA of the bacterial isolates was isolated using the DNeasy Blood \& Tissue kit (Qiagen Inc., Valencia, CA, USA). The standard $16 \mathrm{~S}$ ribosomal RNA (rRNA) gene primers and RNA polymerase $\alpha$ subunit gene rpoA primers were used for PCR to amplify the 16S rRNA gene and rpoA gene sequences of the bacterial isolates, respectively (Weisburg et al., 1990; Naser et al., 2005). The resultant PCR products were sequenced by an automatic sequencing service provided by Genomics Biotech Inc., (New Taipei City, Taiwan). The nucleotide sequences of the $16 \mathrm{~S}$ rRNA and rpoA genes were aligned using the National Center for Biotechnology Information's Basic Local Alignment Search Tool (BLAST).

For the determination of biochemical characteristics, the carbon source use profiles of the LAB isolates were determined using an API $50 \mathrm{CH}$ system (bioMerieux, Inc., Marcy l'Etoile, France) according to the manufacturer's instructions. For the determination of physiological characteristics, the LAB isolates were cultured at $10^{\circ} \mathrm{C}, 37^{\circ} \mathrm{C}, \mathrm{pH} 4.8$, or in the presence of $10 \%$ ethanol according to the methods described by Lin et al. (1999).

\section{Cytotoxicity Assay of the LAB Isolates}

Before the anti-PEDV activity assay, the cytotoxicity of the $\mathrm{LAB}$ isolates on the African green monkey kidney cell line Vero was evaluated according to the method described by Mosmann (1983). The Vero C1008 cells were purchased from the Bioresource Collection and Research Center of Food Industry Research and Development Institute (BCRC, Hsinchu, Taiwan) and were routinely grown at $37^{\circ} \mathrm{C}$ in a humidified atmosphere of $95 \%$ air and $5 \% \mathrm{CO}_{2}$ in Dulbecco's modified Eagle's medium (DMEM, Gibco, Grand Island, NY, USA) supplemented with $10 \%$ fetal bovine serum (FBS; Moregate Biotech., Queensland, Australia).

For evaluation of cytotoxicity, a $1.0-\mathrm{ml}$ aliquot of the $16-\mathrm{h}$ culture of each bacterial strain was centrifuged at $9,000 \mathrm{~g}$ for $10 \mathrm{~min}$ at $4^{\circ} \mathrm{C}$. The bacteria were collected, washed twice with sterile phosphate-buffered saline (PBS; $0.1 \mathrm{M}, \mathrm{pH}$ 7.0), resuspended in $1.0 \mathrm{ml}$ of sterile $\mathrm{PBS}$, and sonicated for $10 \mathrm{~min}$ with an ultrasonicator (Model XL, Misonix, Farmingdale, $\mathrm{NY}$ ). The sonicated bacteria were fractioned into intracellular extracts and cell-wall pellet fractions by subsequent centrifugation at $13,000 \mathrm{~g}$ for $20 \mathrm{~min}$ at $4^{\circ} \mathrm{C}$. The intracellular extracts were harvested, and the cytotoxicity on Vero cells was determined using the 3-(4,5-dimethylthiazol-2-yl)-2,5diphenyltetrazolium bromide (MTT) assay according to the method described by Mosmann (1983). Briefly, Vero cells were seeded at a density of $1.5 \times 10^{5}$ cells/well on a 24 -well plate in $500 \mu \mathrm{l}$ of DMEM. After incubating at $37^{\circ} \mathrm{C}$ for $24 \mathrm{~h}$, $100 \mu \mathrm{l}$ of the bacterial intracellular extracts were added into each well and incubated at $37^{\circ} \mathrm{C}$ for another $24 \mathrm{~h}$. After washing twice with sterile PBS, the cells were incubated with $500 \mu \mathrm{l}$ of MTT $\left(5 \mathrm{mg} / \mathrm{ml}\right.$ in PBS) at $37^{\circ} \mathrm{C}$ for $2 \mathrm{~h}$. After the incubation, the medium was removed, and $200 \mu \mathrm{l}$ of dimethyl sulfoxide (DMSO) were added into each well to dissolve the formazan crystals. The absorbance was measured at $570 \mathrm{~nm}$ using a microplate reader (Victor ${ }^{3}$, PerkinElmer Inc., Waltham, MA, USA), and percentages of cell metabolic activity were calculated as follows:

$$
\begin{aligned}
\text { Metabolic activity }(\%)= & \text { Absorbance of Sample } / \\
& \text { Absorbance of Control } \times 100
\end{aligned}
$$

where the Absorbance of Sample is the absorbance of cells treated with test sample and the Absorbance of Control is the absorbance of cells treated with DMSO.

\section{Assessment of the in vitro Prophylactic Effects of LAB Against PEDV}

The PEDV Taiwan Pintung 52 strain was isolated in early 2014 from the intestinal homogenate of a 7-day-old suckling pig in Taiwan and adapted to Vero cells as previously described by Chang et al. (2017). Viral infection and propagation were performed in Vero cells according to the method described by Chang et al. (2017).

Before the anti-PEDV activity screening experiments were conducted, the viral titers of PEDV were adjusted to 200 fifty-percent tissue culture infective dose $\left(\mathrm{TCID}_{50}\right) / \mathrm{ml}$, and the intracellular extracts of bacterial isolates were prepared as described above. Vero cells were seeded at a density of $3 \times 10^{4}$ cells/well on a 96-well plate in $100 \mu \mathrm{l}$ of modified postinoculation (PI) medium containing DMEM (Gibco, Grand Island, NY, USA) supplemented with tryptose phosphate broth $(0.3 \%)$, yeast extract $(0.02 \%)$, and $10 \mu \mathrm{g} / \mathrm{ml}$ of trypsin. After incubating at $37^{\circ} \mathrm{C}$ for $24 \mathrm{~h}, 100 \mu \mathrm{l}$ of the bacterial intracellular extracts were added into each well and incubated at $37^{\circ} \mathrm{C}$ for another $24 \mathrm{~h}$. After washing the cells twice with PI medium, $200 \mu \mathrm{l}$ of PI medium containing $200 \mathrm{TCID}_{50} / \mathrm{ml}$ of the PEDV was added into each well and incubated at $37^{\circ} \mathrm{C}$ for $1 \mathrm{~h}$. After $1 \mathrm{~h}$ of incubation, the supernatants were replaced by fresh PI medium and the cells were maintained at $37^{\circ} \mathrm{C}$ for $48 \mathrm{~h}$. After washing twice with sterile PBS (0.1 M, pH 7.0), the cell metabolic activity was determined using the MTT assay as described previously.

\section{Assessment of the in vitro Prophylactic Effects of LAB Intracellular Extract, Cell-Wall Fraction, and Extracellular Supernatant Against PEDV}

A $1.0-\mathrm{ml}$ aliquot of the 16-h culture of each LAB strain was centrifuged at $9,000 \mathrm{~g}$ for $10 \mathrm{~min}$ at $4^{\circ} \mathrm{C}$. The resultant extracellular supernatants and bacterial cells were harvested separately. The bacterial cells were washed twice with sterile PBS, resuspended in $1.0 \mathrm{ml}$ of sterile PBS, and sonicated for $10 \mathrm{~min}$ with an 
TABLE 1 | Primer list.

\begin{tabular}{|c|c|c|c|}
\hline Gene & Primer sequence $\left.\left(5^{\prime}-3\right)^{\prime}\right)$ & Application & References \\
\hline $16 \mathrm{~S}$ ribosomal RNA (rRNA) & Forward: AGAGTTGATCMTGGCTCAG & \multirow[t]{2}{*}{$\mathrm{PCR}$} & \multirow[t]{2}{*}{ Weisburg et al. (1990) } \\
\hline rpoA & $\begin{array}{l}\text { Reverse: GGTTACCTTGTTACGACTT } \\
\text { Forward: ATGATYGARTTTGAAAACC }\end{array}$ & & \\
\hline Oligoadenylate synthetase 1 (OAS1) & $\begin{array}{l}\text { Reverse: ACHGTRTTRATDCCDGCRCG } \\
\text { Forward: GGTTGTCTTCCTCAGTCCTC }\end{array}$ & PCR & Naser et al. (2005) \\
\hline & Reverse: AGCCTGGACCTCAAACTTCA & $\begin{array}{l}\text { Quantitative reverse-transcription PCR } \\
\text { (qRT-PCR) }\end{array}$ & Shen et al. (2016) \\
\hline Myxovirus resistance 1 (MX1) & Forward: GCAGCCAGTACGAGGAGAAG & \multirow[t]{2}{*}{ qRT-PCR } & \multirow[t]{2}{*}{ Shen et al. (2016) } \\
\hline Interferon-stimulated gene 15 (ISG15) & $\begin{array}{l}\text { Reverse: CTCCTGACAGTGCCTCCAAC } \\
\text { Forward: GGGCAACGAGTTCCAGGT }\end{array}$ & & \\
\hline \multirow{2}{*}{$\begin{array}{l}\text { Glyceraldehyde 3-phosphate } \\
\text { dehydrogenase (GAPDH) }\end{array}$} & $\begin{array}{l}\text { Reverse: CACCACCAGCAGGACCGT } \\
\text { Forward: AGCCAAAAGGGTCATCATCT }\end{array}$ & qRT-PCR & Shen et al. (2016) \\
\hline & Reverse: ATGAGTCCTTCCACGATACC & qRT-PCR & Shen et al. (2016) \\
\hline
\end{tabular}

ultrasonicator (Model XL, Misonix, Farmingdale, NY, USA). The sonicated bacterial cells were fractioned into intracellular extracts and cell-wall pellet fractions by subsequent centrifugation at $13,000 \mathrm{~g}$ for $20 \mathrm{~min}$ at $4^{\circ} \mathrm{C}$. The extracellular supernatants, intracellular extracts, and cell-wall fractions of each bacterial strain were harvested, and the anti-PEDV activities were evaluated as described above.

\section{Assessment of the in vitro Therapeutic Effects of LAB Against PEDV}

Vero cells were seeded on a 96-well plate and incubated at $37^{\circ} \mathrm{C}$ for $24 \mathrm{~h}$. Afterward, the cells were washed with PI medium, and $200 \mu \mathrm{l}$ of PI medium containing $200 \mathrm{TCID}_{50} / \mathrm{ml}$ of PEDV were added into each well and incubated at $37^{\circ} \mathrm{C}$ for $1 \mathrm{~h}$. After $1 \mathrm{~h}$ of incubation, the supernatants were replaced by $100 \mu \mathrm{l}$ of fresh PI medium and $100 \mu \mathrm{l}$ of the bacterial intracellular extracts. The cells were maintained at $37^{\circ} \mathrm{C}$ for 48 h. After washing twice with sterile PBS, the cell metabolic activity was determined by MTT assay as described previously.

\section{Assessment of the in vitro Direct-Inhibitory Effects of LAB Against PEDV}

Vero cells were seeded on a 96-well plate and incubated at $37^{\circ} \mathrm{C}$ for $24 \mathrm{~h}$. After the cells were washed twice with PI medium, $100 \mu \mathrm{l}$ of the bacterial intracellular extracts and $100 \mu \mathrm{l}$ of PI medium containing $200 \mathrm{TCID}_{50} / \mathrm{ml}$ of PEDV were added into each well and incubated at $37^{\circ} \mathrm{C}$ for $1 \mathrm{~h}$. After $1 \mathrm{~h}$ of incubation, the supernatants were replaced by $200 \mu \mathrm{l}$ of fresh PI medium and the cells were maintained at $37^{\circ} \mathrm{C}$ for $48 \mathrm{~h}$. After washing twice with sterile PBS, the cell metabolic activity was determined by MTT assay as described previously.

\section{Quantitative Reverse-Transcription PCR for Quantification of Type 1 IFN-Dependent Genes}

The expression levels of Type 1 IFN-dependent genes, including OAS1, MX1, and ISG15, were quantified in Vero cells. Vero cells were seeded and incubated at $37^{\circ} \mathrm{C}$ for $24 \mathrm{~h}$. After washing twice with sterile PBS, the Vero cells were treated with the bacterial intracellular extracts, human IFN- $\alpha 2 b$, or PBS and incubated at $37^{\circ} \mathrm{C}$ for up to $48 \mathrm{~h}$. During the incubation, the Vero cells were harvested at 0,24 , or $48 \mathrm{~h}$, and total RNA was extracted by using TRizol reagent (Invitrogen, Carlsbad, CA, USA). Residual DNA was removed with RNase-free DNase I (Invitrogen) treatment. RNA concentrations were measured in triplicate using a NanoDrop spectrophotometer (NanoDrop Technologies Inc., Wilmington, DE, USA). Complementary DNA (cDNA) was prepared from total RNA with a HighCapacity cDNA Reverse Transcription Kit (Applied Biosystems, Foster City, CA, USA) with random hexamer primers. The gene expression analysis was done by Quantitative ReverseTranscription PCR (qRT-PCR) using a KAPA SYBR FAST qPCR Master Mix Kit (Kapa Biosystems, Wilmington, MA, USA) on a LightCycler 480 System (Roche Applied Science, Indianapolis, IN, USA). Glyceraldehyde 3-phosphate dehydrogenase (GAPDH) was chosen as an internal control, and all relative gene expression levels were normalized to GAPDH by the comparative $\mathrm{C}_{\mathrm{T}}$ method. The primers used for the relative quantification are provided in Table 1.

\section{Statistical Analysis}

The data were analyzed using SPSS version 25 software (IBM SPSS, New York, NY, USA). One-way analysis of variance (ANOVA) followed by Duncan's multiple range test was used to detect the differences among the means of the different treatment groups, and a value of $p$ less than 0.05 was considered significant. Student's $t$-test was used to detect the differences between the treatment and control groups, and a value of $p$ less than 0.05 was considered significant. Each experiment was conducted in triplicate, and all results were expressed as means \pm standard deviations.

\section{RESULTS}

\section{Molecular Identification of the LAB Strains Isolated From Kefir Grains}

Twenty-nine LAB strains were isolated from kefir grains. According to the 16S rRNA and rpoA gene sequence analysis, three isolated strains belong to the species Enterococcus durans, 
16 isolated strains might belong to the species Lactobacillus kefiri, five isolated strains might belong to the species Lactococcus lactis, and five isolated strains might belong to the species Leuconostoc mesenteroides (Table 2).

\section{In vitro Prophylactic Effects of LAB Against PEDV}

The in vitro prophylactic effects of the LAB strains on PEDV were evaluated in the Vero cell model. Vero cells were pretreated with the intracellular extracts of LAB for $24 \mathrm{~h}$. After the removal of the bacterial intracellular extracts, the Vero cells were infected with PEDV. If the intracellular extracts of $L A B$ possessed an in vitro prophylactic effect against PEDV, the bacterial pretreated Vero cells would be infected with less PEDV and thus would show higher cell metabolic activity than the un-pretreated cells. The in vitro prophylactic effects of the bacterial intracellular extracts of different $\mathrm{LAB}$ species against PEDV were compared, and human IFN- $\alpha 2 b$ was used as a positive control. Vero cells pretreated with IFN- $\alpha 2 \mathrm{~b}$ prior to PEDV infection showed a significantly higher cell metabolic activity and less cytopathic effects than the un-pretreated cells

TABLE 2 | Identification of bacterial strains based on 16S rRNA and rpoA sequence analysis.

\begin{tabular}{|c|c|c|c|}
\hline Strain ID & $\begin{array}{l}\text { Closely related } \\
\text { validly published } \\
\text { taxa }\end{array}$ & $\begin{array}{l}\text { Sequence } \\
\text { similarity of } 165 \\
\text { rRNA gene (\%) }\end{array}$ & $\begin{array}{l}\text { Sequence } \\
\text { similarity of rpoA } \\
\text { gene (\%) }\end{array}$ \\
\hline YPK1 & Enterococcus durans & 99.93 & 100.00 \\
\hline YPK2 & $\begin{array}{l}\text { Leuconostoc } \\
\text { mesenteroides }\end{array}$ & 99.86 & 99.72 \\
\hline YPK3 & Lactobacillus kefiri & 99.79 & 100.00 \\
\hline YPK4 & Lactobacillus kefiri & 99.86 & 100.00 \\
\hline YPK5 & $\begin{array}{l}\text { Leuconostoc } \\
\text { mesenteroides }\end{array}$ & 100.00 & 99.58 \\
\hline YPK6 & Lactobacillus kefiri & 100.00 & 100.00 \\
\hline YPK7 & Lactobacillus kefiri & 99.86 & 100.00 \\
\hline YPK8 & Lactobacillus kefiri & 99.79 & 100.00 \\
\hline YPK9 & Lactobacillus kefiri & 99.65 & 100.00 \\
\hline YPK10 & Lactobacillus kefiri & 99.72 & 100.00 \\
\hline YPK11 & Lactococcus lactis & 99.64 & 99.29 \\
\hline YPK12 & Lactobacillus kefiri & 99.79 & 100.00 \\
\hline YPK13 & Enterococcus durans & 99.93 & 99.86 \\
\hline YPK14 & Lactobacillus kefiri & 99.72 & 100.00 \\
\hline YPK15 & Lactobacillus kefiri & 99.72 & 100.00 \\
\hline YPK16 & Lactococcus lactis & 99.93 & 100.00 \\
\hline YPK17 & Lactobacillus kefiri & 99.58 & 100.00 \\
\hline YPK18 & $\begin{array}{l}\text { Leuconostoc } \\
\text { mesenteroides }\end{array}$ & 99.79 & 99.86 \\
\hline YPK19 & Lactococcus lactis & 99.93 & 99.72 \\
\hline YPK20 & Lactococcus lactis & 99.93 & 99.57 \\
\hline YPK22 & Lactobacillus kefiri & 99.79 & 100.00 \\
\hline YPK23 & Lactococcus lactis & 99.93 & 99.58 \\
\hline YPK24 & Enterococcus durans & 99.93 & 100.00 \\
\hline YPK25 & $\begin{array}{l}\text { Leuconostoc } \\
\text { mesenteroides }\end{array}$ & 100.00 & 99.86 \\
\hline YPK26 & Lactobacillus kefiri & 99.72 & 100.00 \\
\hline YPK27 & Lactobacillus kefiri & 100.00 & 100.00 \\
\hline YPK28 & Lactobacillus kefiri & 99.58 & 100.00 \\
\hline YPK29 & Lactobacillus kefiri & 99.72 & 100.00 \\
\hline YPK30 & $\begin{array}{l}\text { Leuconostoc } \\
\text { mesenteroides }\end{array}$ & 99.93 & 99.57 \\
\hline
\end{tabular}

(Figures 1, 2), indicating that IFN- $\alpha 2 \mathrm{~b}$ possessed an in vitro prophylactic effect against PEDV. Among the cells pretreated with the intracellular extracts of different LAB species, the cells pretreated with the intracellular extracts of Ln. mesenteroides showed significantly higher cell metabolic activity than those pretreated with the intracellular extracts of the other LAB species (Figure 1). In addition, Vero cells pretreated with the intracellular extracts of $L n$. mesenteroides also showed less cytopathic effects than the un-pretreated cells (Figure 2), indicating that $L n$. mesenteroides possessed an in vitro prophylactic effect against PEDV.

\section{In vitro Prophylactic Effects of Ln. mesenteroides Strains Against PEDV}

The in vitro prophylactic effects of the five strains of Ln. mesenteroides isolated from kefir grains on PEDV were further compared with each other. As shown in Figure 3, the metabolic activity of Vero cells pretreated with the intracellular extracts of Ln. mesenteroides, regardless of which strain, were similar to those pretreated with IFN- $\alpha 2 \mathrm{~b}(p>0.05)$ but were significantly higher than the un-pretreated cells $(p<0.05)$, indicating that all the Ln. mesenteroides strains isolated from kefir grains possessed in vitro prophylactic effects against PEDV.

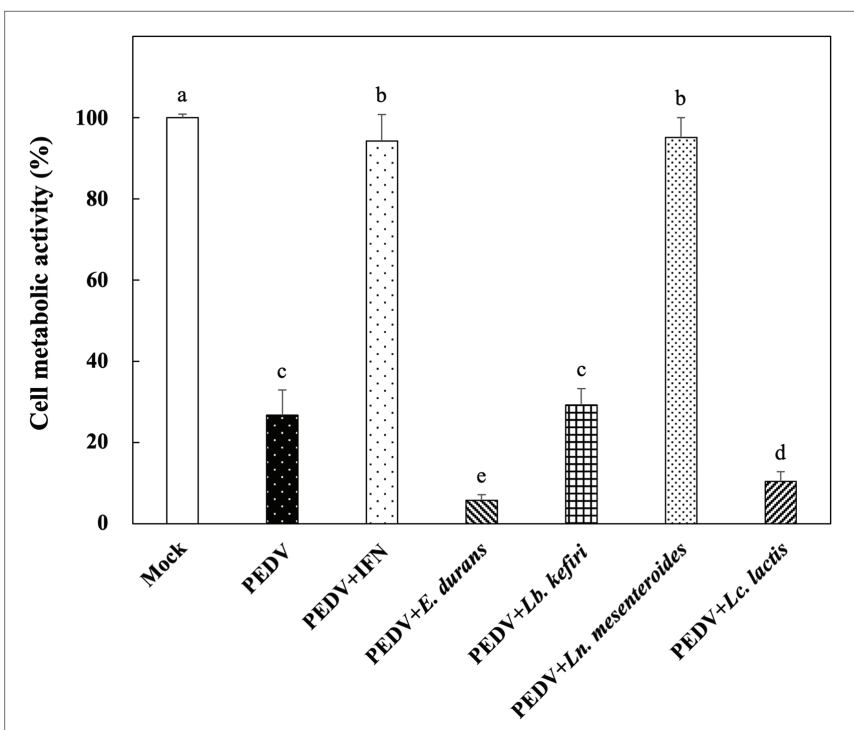

FIGURE 1 | In vitro prophylactic effects of the intracellular extracts of lactic acid bacteria isolated from kefir grains against porcine epidemic diarrhea virus (PEDV) infection in Vero cells. Bar chart showing percentage of cell metabolic activity of seven sample conditions: (1) Mock: cells pretreated with phosphate-buffered saline (PBS) and then mock-infected with PBS, (2) PEDV: cells pretreated with PBS and then infected with PEDV, (3) PEDV+IFN: cells pretreated with interferon (IFN)- $\alpha 2 b$ and then infected with PEDV, (4) PEDV+ E. durans: cells pretreated with the intracellular extracts of Enterococcus durans and then infected with PEDV, (5) PEDV $+L b$. kefiri: cells pretreated with the intracellular extracts of Lactobacillus kefiri and then infected with PEDV, (6) $P E D V+L n$. mesenteroides: cells pretreated with the intracellular extracts of Leuconostoc mesenteroides and then infected with PEDV, and (7) PEDV+ Lc. lactis: cells pretreated with the intracellular extracts of Lactococcus lactis and then infected with PEDV. All data are expressed as mean $\pm \operatorname{SD}(n=3)$. Bars marked with the same letter are not significantly different $(p>0.05)$. 

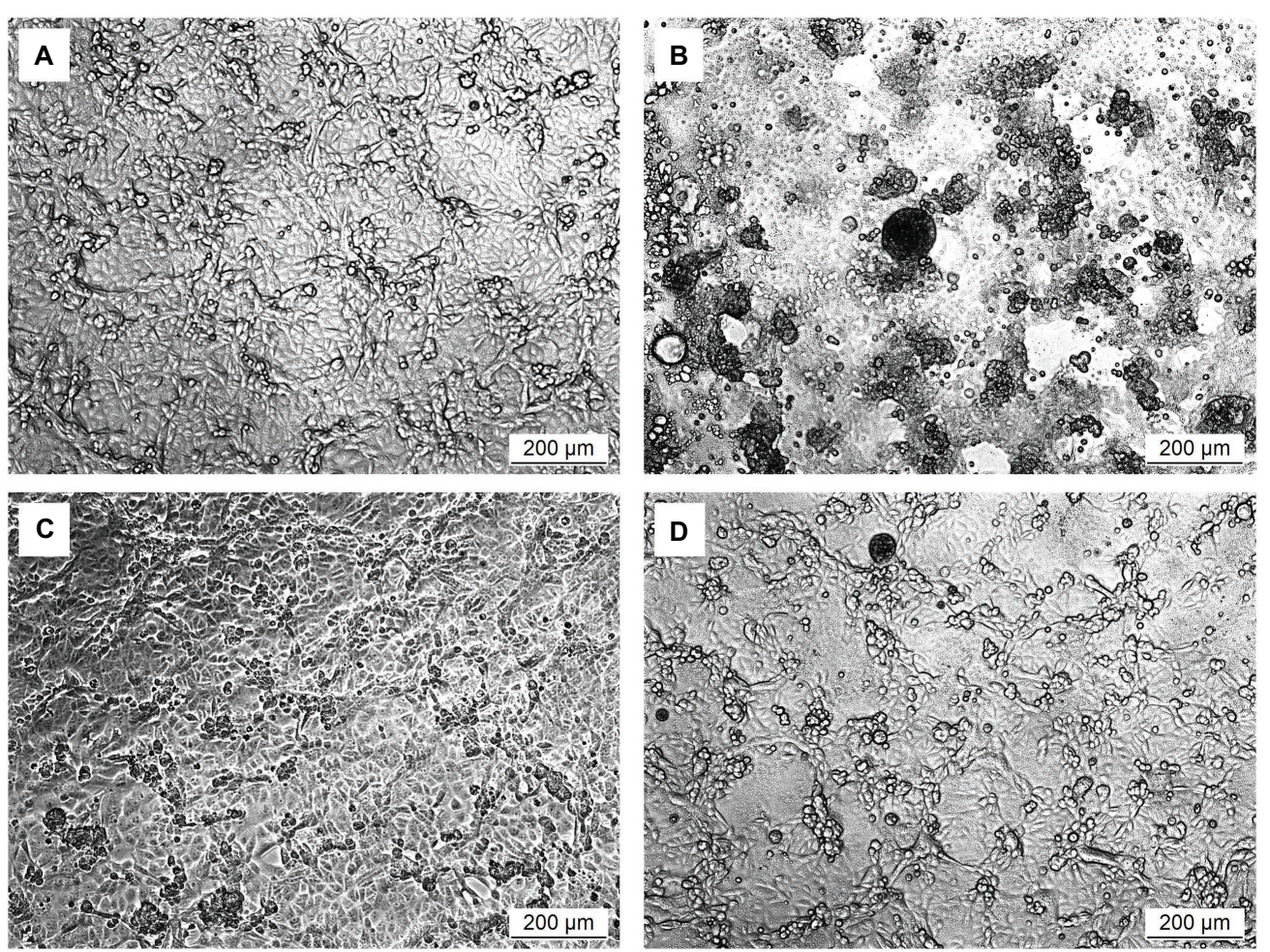

FIGURE 2 | Microscopic observation of the effect of pretreatments on the development of cytopathic effects in Vero cells infected with PEDV. (A) Cells pretreated with PBS and then mock-infected with PBS. (B) Cells pretreated with PBS and then infected with PEDV. (C) Cells pretreated with IFN- $\alpha 2 \mathrm{~b}$ and then infected with PEDV. (D) Cells pretreated with the intracellular extracts of $L n$. mesenteroides isolated from kefir grains and then infected with PEDV.

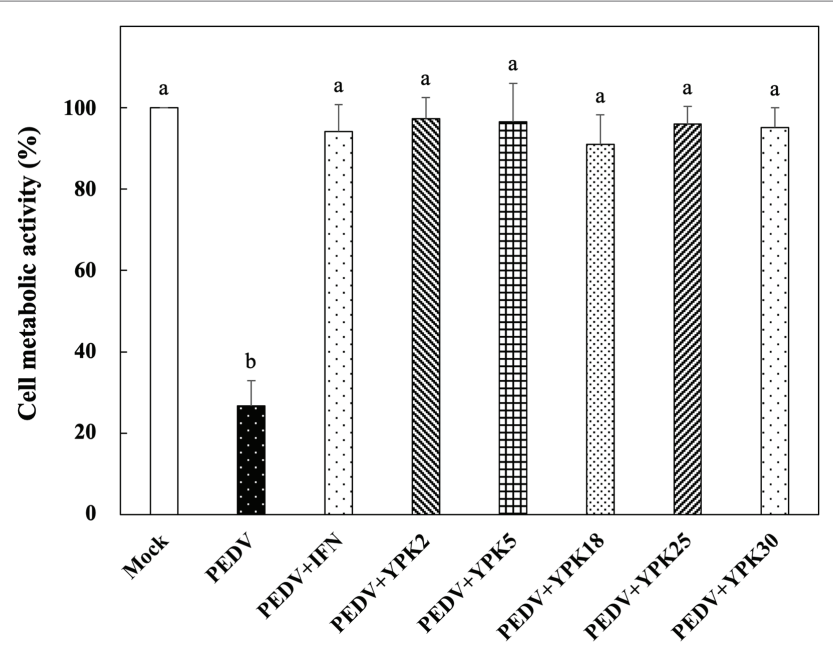

FIGURE 3 | In vitro prophylactic effects of intracellular extracts of different Ln. mesenteroides strains isolated from kefir grains against PEDV infection in Vero cells. Bar chart showing percentage of cell metabolic activity of eight sample conditions: (1) Mock: cells pretreated with PBS and then mock-infected with PBS, (2) PEDV: cells pretreated with PBS and then infected with PEDV, (3) PEDV+IFN: cells pretreated with IFN- $\alpha 2 b$ and then infected with PEDV, (4) PEDV+YPK2, (5) PEDV+YPK5, (6) PEDV+YPK18, (7) PEDV+YPK25, and (8) PEDV+YPK30: cells pretreated with the intracellular extracts of Ln. mesenteroides YPK2, YPK5, YPK18, YPK25, and YPK30 strains, respectively, and then infected with PEDV. All data are expressed as mean $\pm \mathrm{SD}$ $(n=3)$. Bars marked with the same letter are not significantly different $(p>0.05)$.

\section{In vitro Prophylactic Effects of Ln. mesenteroides YPK30 Intracellular Extract, Cell-Wall Fraction, and Extracellular Supernatant Against PEDV}

Among the Ln. mesenteroides strains, a strain designated YPK30 showed a higher growth rate than the other strains (data not shown) and was further evaluated for its basis of anti-PEDV activity. We compared the in vitro prophylactic effects of intracellular extracts, cell-wall fractions, and extracellular supernatants of YPK30 against PEDV. As shown in Figure 4, the metabolic activity of Vero cells pretreated with the intracellular extracts and extracellular supernatants of YPK30 were similar to each other and were significantly higher than those of un-pretreated cells or those pretreated with the cell-wall fractions of YPK30 $(p<0.05)$, indicating that both of the intracellular extracts and extracellular supernatants of YPK30 possessed in vitro prophylactic effects against PEDV.

\section{In vitro Therapeutic Effects of Ln. mesenteroides YPK30 Intracellular Extract Against PEDV}

Vero cells were infected with PEDV for $1 \mathrm{~h}$, and then the remaining PEDV was removed. The PEDV-infected cells were treated with the intracellular extracts of YPK30 or IFN- $\alpha 2 b$ for $48 \mathrm{~h}$, and then the metabolic activities of Vero cells were determined. As shown in Figure 5, PEDV-infected Vero cells treated with the 


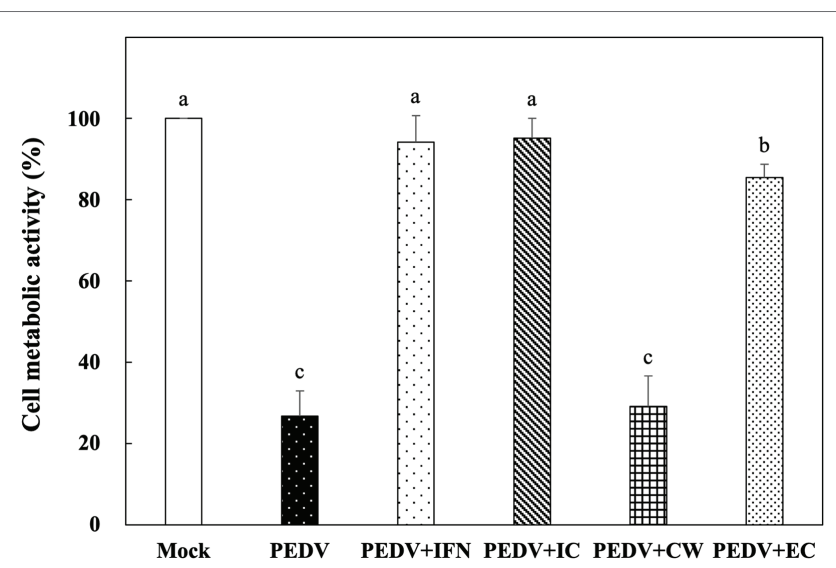

FIGURE 4 | In vitro prophylactic effects of intracellular extracts, cell-wall fractions, or extracellular supernatants of $L n$. mesenteroides YPK30 against PEDV infection in Vero cells. Bar chart showing percentage of cell metabolic activity of six sample conditions: (1) Mock: cells pretreated with PBS and then mock-infected with PBS, (2) PEDV: cells pretreated with PBS and then infected with PEDV, (3) PEDV+IFN: cells pretreated with IFN- $\alpha 2 b$ and then infected with PEDV, (4) PEDV+IC: cells pretreated with the intracellular extracts of $L n$. mesenteroides YPK30 and then infected with PEDV, (5) PEDV+CW: cells pretreated with the cell-wall fractions of $L n$. mesenteroides YPK30 and then infected with PEDV, and (6) PEDV+EC: cells pretreated with the extracellular supernatants of $L n$. mesenteroides YPK30 and then infected with PEDV. All data are expressed as mean $\pm \operatorname{SD}(n=3)$. Bars marked with the same letter are not significantly different $(p>0.05)$.

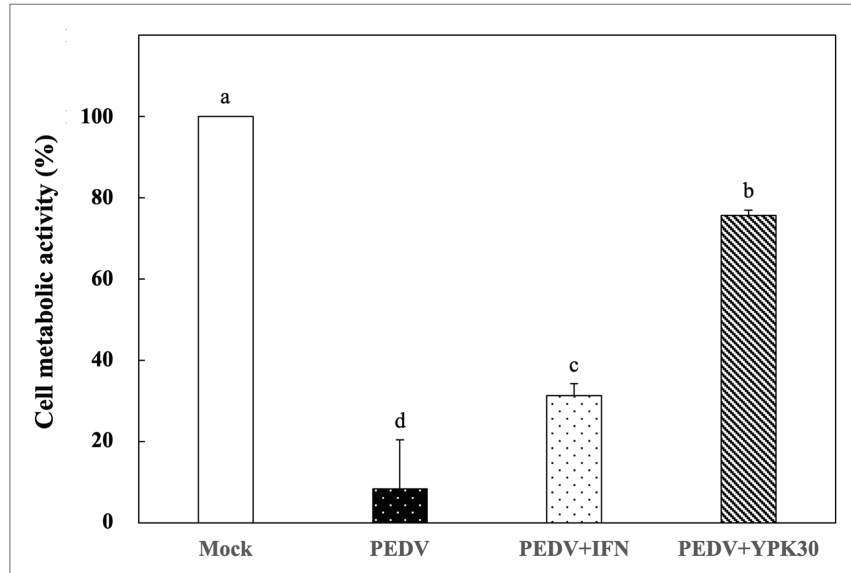

FIGURE 5 | In vitro therapeutic effects of the intracellular extracts of Ln. mesenteroides YPK30 against PEDV infection in Vero cells. Bar chart showing percentage of cell metabolic activity of four sample conditions: (1) Mock: cells mock-infected with PBS and then treated with PBS, (2) PEDV: cells infected with PEDV and then treated with PBS, (3) PEDV+IFN: cells infected with PEDV and then treated with IFN- $\alpha 2 b$, and (4) PEDV+YPK30: cells infected with PEDV and then treated with the intracellular extracts of Ln. mesenteroides YPK30. All data are expressed as mean \pm SD $(n=3)$. Bars marked with the same letter are not significantly different $(p>0.05)$.

intracellular extracts of YPK30 for $48 \mathrm{~h}$ showed higher cell metabolic activity than the untreated cells or those treated with IFN- $\alpha 2 b$ $(p<0.05)$, indicating that the intracellular extracts of the YPK30 strain possessed an in vitro therapeutic effect against PEDV.

\section{In vitro Direct-Inhibitory Effects of Ln. mesenteroides YPK30 Intracellular Extract Against PEDV}

Vero cells were co-incubated with PEDV and the intracellular extracts of YPK30 or IFN- $\alpha 2 b$ for $1 \mathrm{~h}$. After removal of the PEDV and intracellular extracts of YPK30, the Vero cells were incubated for $48 \mathrm{~h}$, and then the metabolic activities of the Vero cells were determined. The metabolic activities of the Vero cells treated with the intracellular extracts of YPK30 and PEDV simultaneously were significantly higher than those treated with PEDV alone or those treated with PEDV and IFN- $\alpha 2 b$ (Figure 6; $p<0.05$ ). These results suggested that the intracellular extracts of YPK30 possessed an in vitro direct-inhibitory effect against PEDV in Vero cells.

\section{Effect of Ln. mesenteroides YPK30 Intracellular Extract on Expression Levels of Type 1 IFN-Dependent Genes}

In order to elucidate the antiviral mechanisms of the YPK30 strain, the expression levels of Type 1 IFN-dependent genes, including $O A S 1, M X 1$, and ISG15, were quantified in Vero cells after 0,24 , or $48 \mathrm{~h}$ of treatment with the intracellular extracts of YPK30. As shown in Figure 7, IFN- $\alpha 2 b$, which served as the positive control, significantly increased the expression levels of OAS1, MX1, and ISG15 genes in Vero cells at 24 and $48 \mathrm{~h}$. The intracellular extracts of YPK30 also significantly increased the expression levels of MX1 and ISG15 genes but did not affect the expression levels of the OAS1 gene in Vero cells at $24 \mathrm{~h}$. However, the expression levels of OAS1, MX1, and ISG15 genes in Vero cells did not differ between the untreated and YPK30-treated groups at $48 \mathrm{~h}$.

\section{Identification of Ln. mesenteroides YPK30}

According to the 16S rRNA and rpoA gene sequence analysis, YPK30 exhibited 99.93 and $99.57 \%$, respectively, identity with Ln. mesenteroides (Table 2), and its $16 \mathrm{~S}$ rRNA and rpoA gene sequences were deposited in the NCBI GenBank database under accession number MT293805 and MT333858, respectively. Macroscopic observation showed that YPK30 exhibited a smooth and grayish white colony morphology and did not possess hemolytic capacity on blood agar plate. The cells of YPK30 appeared purple after Gram staining, indicating the strain YPK30 was Gram positive. Microscopic observation showed the cells of YPK30 were observed as spherical or lenticular forms. Analysis on the basis of phenotypic (including Gramstain-positive, catalase-negative, nonmotile, and asporogenous) and physiological characteristics (including growth at 10 or $37^{\circ} \mathrm{C}$ but not growth at $\mathrm{pH} 4.8$ or in $10 \%$ ethanol) indicated that YPK30 was closely related to species $L n$. mesenteroides. To further confirm the identification of YPK30 with the species Ln. mesenteroides, the biochemical characteristics of YPK30 were compared with those of Ln. mesenteroides subsp. cremoris ATCC 19254, Ln. mesenteroides subsp. dextranicum ATCC 19255, and Ln. mesenteroides subsp. mesenteroides ATCC 8293 by using the API $50 \mathrm{CH}$ system. Analysis of carbon 
source utilization profiles indicated that both YPK30 and Ln. mesenteroides subsp. dextranicum ATCC 19255 grew on six out of 49 carbohydrates, including $N$-acetyl glucosamine, $\mathrm{D}$-fructose, D-glucose, D-mannose, saccharose, and D-trehalose. Distinct variation was observed between YPK30 and Ln. mesenteroides subsp. cremoris ATCC 19254 in the metabolism of the sugars D-fructose, D-mannose, and D-trehalose. Additionally, distinct variation was observed between YPK30 and Ln. mesenteroides subsp. cremoris ATCC 19254 in the metabolism of the carbohydrates amygdaline, L-arabinose, cellobiose, esculine, D-galactose, $\beta$-gentiobiose, D-lactose, maltose, $\alpha$-methyl-D-glucoside, $\mathrm{D}$-raffinose, ribose, $\mathrm{D}$-turanose, and D-xylose. Therefore, the carbon source use characteristics of YPK30 were similar to those of Ln. mesenteroides subsp. dextranicum. According to the results of microscopic observations, biochemical characteristics, and the 16S rRNA and rpoA gene

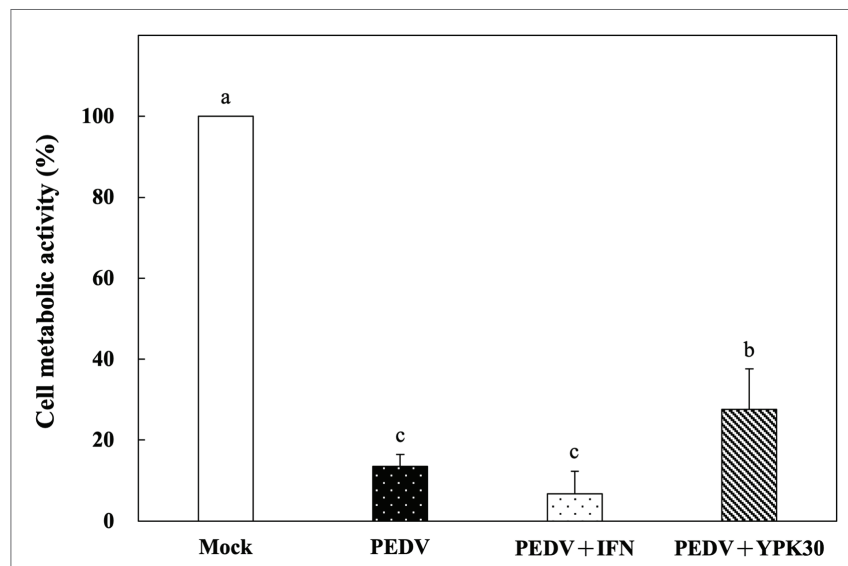

FIGURE 6 | In vitro direct-inhibitory effects of the intracellular extracts of Ln. mesenteroides YPK30 against PEDV infection in Vero cells. Bar chart showing percentage of cell metabolic activity of four sample conditions: (1) Mock: cells incubated with PBS, (2) PEDV: cells infected with PEDV, (3) PEDV+IFN: cells infected with PEDV and simultaneously treated with IFN- $\alpha 2 b$, and (4) PEDV+YPK30: cells infected with PEDV and simultaneously treated with the intracellular extracts of $L n$. mesenteroides YPK30. All data are expressed as mean $\pm \mathrm{SD}(n=3)$. Bars marked with the same letter are not significantly different $(p>0.05)$. sequence analysis, the features of YPK30 were consistent with those of Ln. mesenteroides subsp. dextranicum, as described in Bergey's Manual of Systematic Bacteriology (Vos et al., 2009).

\section{DISCUSSION}

The Vero cell line is one of the most commonly used cell lines for PEDV isolation and propagation (Koonpaew et al., 2019). In this study, we used a Vero cell culture model to evaluate the in vitro prophylactic effects of LAB against PEDV. Four LAB species, including E. durans, Lb. kefiri, Lc. lactis, and Ln. mesenteroides, were isolated from kefir grains, and the in vitro prophylactic effects of the intracellular extracts of these four species against PEDV infection in Vero cells were compared. Among these four LAB species, the intracellular extracts of $L n$. mesenteroides showed a higher in vitro prophylactic effect against PEDV than the other species did (Figure 1). In addition to the in vitro prophylactic effect, the intracellular extracts of Ln. mesenteroides YPK30 also possessed in vitro therapeutic effect and in vitro direct-inhibitory effects against PEDV in Vero cells (Figures 4-6). Vero cells have a major deletion in the Type 1 IFN gene cluster, which results in IFN deficiency (Desmyter et al., 1968; Koonpaew et al., 2019). Although Vero cells do not secrete Type 1 IFNs when infected by viruses, they still have the Type 1 IFN receptors and respond normally to Type 1 IFNs. Therefore, Vero cells were widely used to compare virus-mediated IFN antagonism specific to the IFN signaling pathway (Simmons et al., 2010).

In the in vitro prophylactic and therapeutic models, the intracellular extracts of $\mathrm{Ln}$. mesenteroides YPK30 did not directly interact with PEDV by physical contact. Therefore, the in vitro prophylactic and therapeutic effects of the intracellular extracts of Ln. mesenteroides YPK30 against PEDV in Vero cells seem not be attributed to the direct interaction of bacterial components or metabolites with virus. Since the IFN pathway is crucial in initiating viral resistance, we suggest that the in vitro prophylactic and therapeutic effects of the intracellular extracts of Ln. mesenteroides YPK30 against PEDV in Vero cells could be attributed to its effect on the IFN signaling pathway in Vero cells.
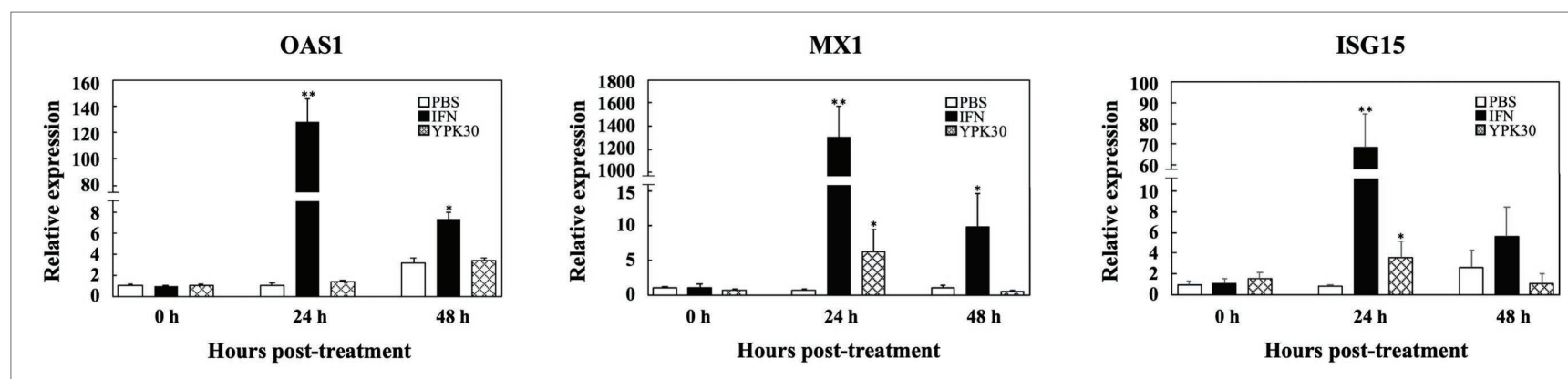

FIGURE 7 | Effect of treatment of intracellular extracts of Ln. mesenteroides YPK30 on the expression levels of Type 1 IFN-dependent genes OAS1, MX1, or ISG15 in Vero cells. Bar charts for each gene showing percentage of cell metabolic activity of three sample conditions: (1) PBS: cells treated with PBS, (2) IFN: cells treated with IFN- $\alpha 2 b$, and (3) YPK30: cells treated with the intracellular extracts of $L n$. mesenteroides YPK30. All data are expressed as mean \pm SD $(n=3)$. Bars marked with a star or double stars mean that they are significantly different from the control (cells treated with PBS) at the 5 or $1 \%$ confidence level, respectively. 
Stimulation of innate immune responses by probiotics could be one of the mechanisms responsible for the protection provided by probiotics against viral infection. Other proposed mechanisms include inhibition of virus adsorption and penetration into cells as a result of direct interaction of probiotics and virus, competition between probiotics and virus for epithelial cell receptors, and secretion of metabolites with antiviral activity (Mousavi et al., 2018; Biliavska et al., 2019). Previous studies have shown that specific probiotic bacteria bind to and inactivate rotaviruses and vesicular stomatitis viruses, which lead to blocking of the virus adsorption on the cell (Salminen et al., 2010; Kanauchi et al., 2018). Besides the direct interaction between probiotics and viruses, specific probiotic bacteria could interact with epithelial and mucosal cells and compete with pathogens for attachment to cell receptors, thereby preventing invasion into the cells by a virus (Fernandez-Duarte et al., 2018; Mousavi et al., 2018). In addition, specific probiotic bacteria could synthesize some antiviral metabolites, such as lactic acid, hydrogen peroxide, or bacteriocins (Al Kassaa et al., 2014). In the present study, the intracellular extracts of Ln. mesenteroides YPK30 possessed an in vitro direct-inhibitory effect against PEDV in Vero cells (Figure 6). Future studies will be aimed at identifying the mechanisms of the in vitro direct-inhibitory effect of the intracellular extracts of $L n$. mesenteroides YPK30 against PEDV in Vero cells.

Numerous mechanisms for the immunomodulatory properties of probiotics have been proposed. Some extracellular polysaccharides produced by specific probiotic bacteria possess immunomodulatory activities, which induce an increase in the expression of IFN- $\alpha$, IFN- $\beta$, and the antiviral factors MX1 and RNase L in porcine intestinal epithelial cells (Kanmani et al., 2018). Beside extracellular polysaccharides, some cellular components, such as DNA and bacterial cell-wall components, including peptidoglycan, S-layer proteins, teichoic acids, capsule, and pellicle, as well as other released peptides could modulate the innate antiviral immune response (Quinteiro-Filho et al., 2015). In the present study, pretreatment of Vero cells with the extracellular supernatants or intracellular extracts of Ln. mesenteroides YPK30 for $24 \mathrm{~h}$ before infection with PEDV showed higher cell metabolic activities than those of un-pretreated cells, indicating that both of the intracellular extracts and extracellular supernatants of Ln. mesenteroides YPK30 possessed in vitro prophylactic effects against PEDV in Vero cells. However, pretreatment of PEDV cells with the cell-wall fractions of $L n$. mesenteroides YPK30 for $24 \mathrm{~h}$ before infection with PEDV did not impede PEDV replication. According to these observations, we suggested that the immunomodulatory activity of Ln. mesenteroides YPK30 seems not to rely on the structural cell components. Future studies should be aimed at assessing the molecular mechanism(s) responsible for the observed effects.

Type 1 IFNs exert their antiviral activities though the induction of hundreds of ISGs (Lenschow et al., 2005). Classical ISGs responsible for inhibition of viral infection include OAS1, MX1, and ISG15 (Schoggins, 2014). OAS1, which belongs to the OAS enzyme family, is activated by double-stranded RNA binding, catalyzes the formation of $2^{\prime}-5^{\prime}$ oligoadenylates to activate cellular RNase L, which in turn, degrade cellular and viral RNA (Choi et al., 2015). MX1 is a dynamin-like GTPase that appears to target viral nucleocapsids, resulting in the inhibition of viral RNA polymerase activity, effectively blocking both transcription and replication of the virus (Schoggins, 2014). ISG15 is a small, ubiquitin-like molecule that has numerous antiviral functions, including inhibition of virus release, ISGylation of both viral and host proteins, and immunomodulatory cytokinelike properties in its unconjugated form (Schoggins, 2014). In the present study, we determined the effects of intracellular extracts of Ln. mesenteroides YPK30 on the expression levels of OAS1, MX1, and ISG15 genes in Vero cells and found that treatment of Vero cells with the intracellular extracts of Ln. mesenteroides YPK30 did not affect the expression levels of the OAS1 gene but significantly increased the expression levels of MX1 and ISG15 genes $24 \mathrm{~h}$ after treatment (Figure 7), indicating that the anti-PEDV activity of the intracellular extracts of Ln. mesenteroides YPK30 could be attributed to its up-regulatory effect on the expression of MX1 and ISG15 genes in Vero cells.

According to the results of microscopic observations, biochemical characteristics, and the 16S rRNA and rpoA gene sequence analysis, YPK30 was identified as Ln. mesenteroides subsp. dextranicum. Ln. mesenteroides are commonly associated with foods, such as fermented dairy products (e.g., cheese, yogurt, and kefir), fermented vegetables (e.g., sauerkraut and kimchi), and fermented meats (Holland and Liu, 2011). The long history of safe consumption of Ln. mesenteroides in traditional fermented foods has led to the conclusion that it is generally regarded as safe (GRAS; Flórez et al., 2016). Several Ln. mesenteroides strains are reported to have anti-listerial, antiviral, or immunomodulatory activities (Seo et al., 2012; Shao et al., 2020). Since the production of exopolysaccharides and bacteriocins are important properties of Ln. mesenteroides, the probiotic characteristics of Ln. mesenteroides could be attributed to their production of exopolysaccharides and bacteriocins. Several studies demonstrated that some bacteriocins produced by $L n$. mesenteroides have anti-pathogenic activities (Stiles, 1994; Holland and Liu, 2011; Arakawa et al., 2016), and some exopolysaccharides produced by $L n$. mesenteroides showed antiviral and immunomodulatory activities (Nácher-Vázquez et al., 2015; Mahdi et al., 2019). In our study, we found that the intracellular extracts of Ln. mesenteroides YPK30 possessed in vitro prophylactic, therapeutic, and direct-inhibitory effects against PEDV in Vero cells, which occur in part through the up-regulation of $M X 1$ and ISG15 expression in Vero cells. To the best of our knowledge, based on a thorough review of the relevant literature, this scientific report is the first of anti-PEDV potential for Ln. mesenteroides. Future research will be conducted to evaluate the protection efficiency of $\mathrm{Ln}$. mesenteroides YPK30 against PEDV infections in piglet infectious challenge models.

\section{CONCLUSION}

The LAB strain YPK30 isolated from kefir grains was genotypically and phenotypically characterized as belonging to Ln. mesenteroides subsp. dextranicum. Ln. mesenteroides subsp. dextranicum YPK30 displayed in vitro prophylactic, therapeutic, and direct-inhibitory effects against PEDV in Vero cells via up-regulation of MX1 and ISG15 expression in Vero cells. These findings suggest 
that $L n$. mesenteroides subsp. dextranicum YPK30 has a potential to acts as an antiviral agent for protection against PEDV infections.

\section{DATA AVAILABILITY STATEMENT}

The datasets presented in this study can be found in online repositories. The names of the repository/repositories and accession number(s) can be found in the article/supplementary material.

\section{AUTHOR CONTRIBUTIONS}

J-RL, W-PC-L, and H-WC contributed to conception and design of the study. W-PC-L, AL, and Y-HC carried out the experiments

\section{REFERENCES}

Al Kassaa, I., Hober, D., Hamze, M., Chihib, N. E., and Drider, D. (2014). Antiviral potential of lactic acid bacteria and their bacteriocins. Probiotics Antimicro. Proteins 6, 177-185. doi: 10.1007/s12602-014-9162-6

Alonso, V. R., and Guarner, F. (2013). Linking the gut microbiota to human health. Br. J. Nutr. 109(Suppl. 2), S21-S26. doi: 10.1017/S0007114512005235

Arakawa, K., Yoshida, S., Aikawa, H., Hano, C., Bolormaa, T., Burenjargal, S., et al. (2016). Production of a bacteriocin-like inhibitory substance by Leuconostoc mesenteroides subsp. dextranicum 213M0 isolated from Mongolian fermented mare milk, airag. Anim. Sci. J. 87, 449-456. doi: 10.1111/asj.12445

Arena, M. P., Capozzi, V., Russo, P., Drider, D., Spano, G., and Fiocco, D. (2018). Immunobiosis and probiosis: antimicrobial activity of lactic acid bacteria with a focus on their antiviral and antifungal properties. Appl. Microbiol. Biotechnol. 102, 9949-9958. doi: 10.1007/s00253-018-9403-9

Azad, M. A. K., Sarker, M., and Wan, D. (2018). Immunomodulatory effects of probiotics on cytokine profiles. Biomed. Res. Int. 2018:8063647. doi: $10.1155 / 2018 / 8063647$

Biliavska, L., Pankivska, Y., Povnitsa, O., and Zagorodnya, S. (2019). Antiviral activity of exopolysaccharides produced by lactic acid bacteria of the genera Pediococcus, Leuconostoc and Lactobacillus against human adenovirus type 5. Medicina 55, 519-512. doi: 10.3390/medicina55090519

Bourrie, B. C. T., Willing, B. P., and Cotter, P. D. (2016). The microbiota and health promoting characteristics of the fermented beverage kefir. Front. Microbiol. 7:647. doi: 10.3389/fmicb.2016.00647

Chang, Y. -C., Kao, C. -F., Chang, C. -Y., Jeng, C. -R., Tsai, P. -S., Pang, V., et al. (2017). Evaluation and comparison of the pathogenicity and host immune responses induced by a G2b Taiwan porcine epidemic diarrhea virus (strain Pintung 52) and its highly cell-culture passaged strain in conventional 5-week-old pigs. Viruses 9:121. doi: 10.3390/v9050121

Choi, U. Y., Kang, J. -S., Hwang, Y. S., and Kim, Y. -J. (2015). Oligoadenylate synthase-like (OASL) proteins: dual functions and associations with diseases. Exp. Mol. Med. 47:e144. doi: 10.1038/emm.2014.110

Desmyter, J., Melnick, J. L., and Rawls, W. E. (1968). Defectiveness of interferon production and of rubella virus interference in a line of African green monkey kidney cells (Vero). J. Virol. 2, 955-961. doi: 10.1128/ JVI.2.10.955-961.1968

Eguchi, K., Fujitani, N., Nakagawa, H., and Miyazaki, T. (2019). Prevention of respiratory syncytial virus infection with probiotic lactic acid bacterium Lactobacillus gasseri SBT2055. Sci. Rep. 9:4812. doi: 10.1038/s41598-019-39602-7

Fernandez-Duarte, K. P., Olaya-Galán, N. N., Salas-Cárdenas, S. P., Lopez-Rozo, J., and Gutierrez-Fernandez, M. F. (2018). Bifidobacterium adolescentis (DSM 20083) and Lactobacillus casei (Lafti L26-DSL): probiotics able to block the in vitro adherence of rotavirus in MA104 cells. Probiotics Antimicro. Proteins 10, 56-63. doi: 10.1007/s12602-017-9277-7

Flórez, A. B., Campedelli, I., Delgado, S., Alegría, Á., Salvetti, E., Felis, G. E., et al. (2016). Antibiotic susceptibility profiles of dairy Leuconostoc, analysis of the genetic basis of atypical resistances and transfer of genes in vitro and in a food matrix. PLoS One 11:e0145203. doi: 10.1371/journal.pone.0145203 and did the data analysis. W-PC-L and J-RL wrote the first draft of the manuscript. All authors contributed to the manuscript revision, read and approved the submitted version. The corresponding author takes primary responsibility for communication with the journal and editorial office during publication.

\section{FUNDING}

This research was conducted using funds partially provided by grants from the Ministry of Science and Technology (grant nos. MOST 108-2313-B-002-012 and MOST 108-2321-B-002064) and Academia Sinica (grant nos. AS-KPQ-108-ITAR-TD03 and AS-KPQ-109-ITAR-TD03).

Fontana, L., Bermudez-Brito, M., Plaza-Diaz, J., Muñoz-Quezada, S., and Gil, A. (2012). Sources, isolation, characterisation and evaluation of probiotics. Br. J. Nutr. 109(Suppl. 2), S35-S50. doi: 10.1017/S0007114512004011

Gerdts, V., and Zakhartchouk, A. (2017). Vaccines for porcine epidemic diarrhea virus and other swine coronaviruses. Vet. Microbiol. 206, 45-51. doi: 10.1016/j. vetmic.2016.11.029

Hao, Z., Fu, F., Cao, L., Guo, L., Liu, J., Xue, M., et al. (2019). Tumor suppressor p53 inhibits porcine epidemic diarrhea virus infection via interferon-mediated antiviral immunity. Mol. Immunol. 108, 68-74. doi: 10.1016/j.molimm. 2019.02.005

Holland, R., and Liu, S. Q. (2011). "Lactic acid bacteria: Leuconostoc spp." in Encyclopedia of dairy sciences. 2nd Edn. eds. J. W. Fuquay, P. E. Fox and P. L. H. McSweeney (Cambridge, Massachusetts, USA: Elsevier), 138-142.

Kanauchi, O., Andoh, A., AbuBakar, S., and Yamamoto, N. (2018). Probiotics and paraprobiotics in viral infection: clinical application and effects on the innate and acquired immune systems. Curr. Pharm. Des. 24, 710-717. doi: $10.2174 / 1381612824666180116163411$

Kanmani, P., Albarracin, L., Kobayashi, H., Iida, H., Komatsu, R., Humayun Kober, A. K. M., et al. (2018). Exopolysaccharides from Lactobacillus delbrueckii OLL1073R-1 modulate innate antiviral immune response in porcine intestinal epithelial cells. Mol. Immunol. 93, 253-265. doi: 10.1016/j.molimm.2017.07.009

Koonpaew, S., Teeravechyan, S., Frantz, P. N., Chailangkarn, T., and Jongkaewwattana, A. (2019). PEDV and PDCoV pathogenesis: the interplay between host innate immune responses and porcine enteric coronaviruses. Front. Vet. Sci. 6:34. doi: $10.3389 /$ fvets.2019.00034

Lee, C. (2015). Porcine epidemic diarrhea virus: an emerging and re-emerging epizootic swine virus. Virol. J. 12:193. doi: 10.1186/s12985-015-0421-2

Lenschow, D. J., Giannakopoulos, N. V., Gunn, L. J., Johnston, C., O'Guin, A. K., Schmidt, R. E., et al. (2005). Identification of interferon-stimulated gene 15 as an antiviral molecule during Sindbis virus infection in vivo. J. Virol. 79, 13974-13983. doi: 10.1128/JVI.79.22.13974-13983.2005

Lin, C. W., Chen, H. L., and Liu, J. R. (1999). Identification and characterisation of lactic acid bacteria and yeasts isolated from kefir grains in Taiwan. Aust. J. Dairy Technol. 54, 14-18.

Liu, X., Cao, S., and Zhang, X. (2015). Modulation of gut microbiota-brain axis by probiotics, prebiotics, and diet. J. Agric. Food Chem. 63, 7885-7895. doi: $10.1021 /$ acs.jafc.5b02404

Llewellyn, A., and Foey, A. (2017). Probiotic modulation of innate cell pathogen sensing and signaling events. Nutrients 9:1156. doi: 10.3390/nu9101156

Mahdi, L. H., Hussein, N. H., Taha, B. M., Auda, I. G., Zwain, L. A. H., and Mater, H. N. (2019). Immunostimulatory and antibacterial activity of Leuconostoc mesenteroides and its purified exopolysaccharide against extendedspectrum beta-lactamase producing Burkholderia cepacia. Rev. Med. Microbiol. 30, 161-172. doi: 10.1097/MRM.0000000000000172

Marangon, S., and Busani, L. (2007). The use of vaccination in poultry production. Rev. Sci. Tech. 26, 265-274. doi: 10.20506/rst.26.1.1742

Marshall, V. M., and Cole, W. M. (1985). Methods for making kefir and fermented milks based on kefir. J. Dairy Res. 52, 451-456. doi: 10.1017/ S0022029900024353 
Meng, X. J. (2012). Emerging and re-emerging swine viruses. Transbound. Emerg. Dis. 59(Suppl. 1), 85-102. doi: 10.1111/j.1865-1682.2011.01291.x

Mosmann, T. (1983). Rapid colorimetric assay for cellular growth and survival: application to proliferation and cytotoxicity assays. J. Immunol. Methods 65, 55-63. doi: 10.1016/0022-1759(83)90303-4

Mousavi, E., Makvandi, M., Teimoori, A., Ataei, A., Ghafari, S., and Samarbaf-Zadeh, A. (2018). Antiviral effects of Lactobacillus crispatus against HSV-2 in mammalian cell lines. J. Chin. Med. Assoc. 81, 262-267. doi: 10.1016/j.jcma.2017.07.010

Nácher-Vázquez, M., Ballesteros, N., Canales, Á., Rodríguez Saint-Jean, S., Pérez-Prieto, S. I., Prieto, A., et al. (2015). Dextrans produced by lactic acid bacteria exhibit antiviral and immunomodulatory activity against salmonid viruses. Carbohydr. Polym. 124, 292-301. doi: 10.1016/j.carbpol.2015.02.020

Naser, S. M., Thompson, F. L., Hoste, B., Gevers, D., Dawyndt, P., Vancanneyt, M., et al. (2005). Application of multilocus sequence analysis (MLSA) for rapid identification of Enterococcus species based on rpoA and pheS genes. Microbiology 151, 2141-2150. doi: 10.1099/mic.0.27840-0

Prado, M. R., Blandón, L. M., Vandenberghe, L. P. S., Rodrigues, C., Castro, G. R., Thomaz-Soccol, V., et al. (2015). Milk kefir: composition, microbial cultures, biological activities, and related products. Front. Microbiol. 6:1177. doi: 10.3389/fmicb.2015.01177

Quinteiro-Filho, W. M., Brisbin, J. T., Hodgins, D. C., and Sharif, S. (2015). Lactobacillus and Lactobacillus cell-free culture supernatants modulate chicken macrophage activities. Res. Vet. Sci. 103, 170-175. doi: 10.1016/j.rvsc.2015.10.005

Salminen, S., Nybom, S., Meriluoto, J., Collado, M. C., Vesterlund, S., and El-Nezami, H. (2010). Interaction of probiotics and pathogens-benefits to human health? Curr. Opin. Biotechnol. 21, 157-167. doi: 10.1016/j.copbio.2010.03.016

Schoggins, J. W. (2014). Interferon-stimulated genes: roles in viral pathogenesis. Curr. Opin. Virol. 6, 40-46. doi: 10.1016/j.coviro.2014.03.006

Seo, B. J., Rather, I. A., Kumar, V. J. R., Choi, U. H., Moon, M. R., Lim, J. H., et al. (2012). Evaluation of Leuconostoc mesenteroides YML003 as a probiotic against low-pathogenic avian influenza (H9N2) virus in chickens. J. Appl. Microbiol. 113, 163-171. doi: 10.1111/j.1365-2672.2012.05326.x

Shao, X., Fang, K., Medina, D., Wan, J., Lee, J. L., and Hong, S. H. (2020). The probiotic, Leuconostoc mesenteroides, inhibits Listeria monocytogenes biofilm formation. J. Food Saf. 40:e12750. doi: 10.1111/jfs.12750

Shen, H., Zhang, C., Guo, P., Liu, Z., Sun, M., Sun, J., et al. (2016). Short communication: antiviral activity of porcine IFN- $\lambda 3$ against porcine epidemic diarrhea virus in vitro. Virus Genes 52, 877-882. doi: 10.1007/s11262-016-1374-2

Simmons, J. D., Wollish, A. C., and Heise, M. T. (2010). A determinant of Sindbis virus neurovirulence enables efficient disruption of Jak/STAT signaling. J. Virol. 84, 11429-11439. doi: 10.1128/JVI.00577-10
Stiles, M. E. (1994). Bacteriocins produced by Leuconostoc species. J. Dairy Sci. 77, 2718-2724. doi: 10.3168/jds.S0022-0302(94)77214-3

Villena, J., Vizoso-Pinto, M. G., and Kitazawa, H. (2016). Intestinal innate antiviral immunity and immunobiotics: beneficial effects against rotavirus infection. Front. Immunol. 7:563. doi: 10.3389/fimmu.2016.00563

Vinderola, C. G., Prosello, W., Ghiberto, D., and Reinheimer, J. A. (2000). Viability of probiotic (Bifidobacterium, Lactobacillus acidophilus and Lactobacillus casei) and nonprobiotic microflora in Argentinian Fresco cheese. J. Dairy Sci. 83, 1905-1911. doi: 10.3168/jds.S0022-0302(00)75065-X

Vos, P., Garrity, P., Jones, D., Krieg, N. R., Ludwig, W., Rainey, F. A., et al. (2009). Bergey's manual of systematic bacteriology: Volume 3: The firmicutes. 2nd Edn. eds. P. Vos, G. Garrity, D. Jones, N. R. Krieg, W. Ludwig and F. A. Rainey et al. (New York, USA: Springer).

Wang, S. -Y., Chen, K. -N., Lo, Y. -M., Chiang, M. -L., Chen, H. -C., Liu, J. -R., et al. (2012). Investigation of microorganisms involved in biosynthesis of the kefir grain. Food Microbiol. 32, 274-285. doi: 10.1016/j.fm.2012.07.001

Wang, Q., Vlasova, A. N., Kenney, S. P., and Saif, L. J. (2019). Emerging and re-emerging coronaviruses in pigs. Curr. Opin. Virol. 34, 39-49. doi: 10.1016/j. coviro.2018.12.001

Weisburg, W. G., Barns, S. M., Pelletier, D. A., and Lane, D. J. (1990). 16S ribosomal DNA amplification for phylogenetic study. J. Bacteriol. 173, 697-703.

Yadav, M., and Shukla, P. (2019). Recent systems biology approaches for probiotics use in health aspects: a review. 3 Biotech 9:448. doi: 10.1007/ s13205-019-1980-5

Zelaya, H., Tada, A., Vizoso-Pinto, M. G., Salva, S., Kanmani, P., Agüero, G., et al. (2015). Nasal priming with immunobiotic Lactobacillus rhamnosus modulates inflammation-coagulation interactions and reduces influenza virus-associated pulmonary damage. Inflamm. Res. 64, 589-602. doi: 10.1007/ s00011-015-0837-6

Conflict of Interest: The authors declare that the research was conducted in the absence of any commercial or financial relationships that could be construed as a potential conflict of interest.

Copyright (c) 2020 Chang-Liao, Lee, Chiu, Chang and Liu. This is an open-access article distributed under the terms of the Creative Commons Attribution License (CC BY). The use, distribution or reproduction in other forums is permitted, provided the original author(s) and the copyright owner(s) are credited and that the original publication in this journal is cited, in accordance with accepted academic practice. No use, distribution or reproduction is permitted which does not comply with these terms. 